\title{
Palynological perspectives on vegetation survey: a critical step for model-based reconstruction of Quaternary land cover
}

\author{
M.J. Bunting ${ }^{\mathrm{a}, *}$, M. Farrell ${ }^{\mathrm{a}}$, A. Broström ${ }^{\mathrm{b}}$, K.L. Hjelle ${ }^{\mathrm{c}}$, F. Mazier ${ }^{\mathrm{b}, \mathrm{d}}$, R. Middleton ${ }^{\mathrm{a}}$, \\ A.B. Nielsen ${ }^{b}$, E. Rushton ${ }^{\text {e }}$, H. Shaw ${ }^{\text {f }}$, C.L. Twiddle ${ }^{g}$ \\ a Department of Geography, Environment and Earth Sciences, University of Hull, Cottingham Road, Hull, HU6 7RX, UK \\ ${ }^{\mathrm{b}}$ Department of Geology, Lund University, Lund, Sweden \\ ${ }^{\mathrm{c}}$ The Natural History Collections, University of Bergen, Allégt. 41, N-5007 Bergen, Norway \\ ${ }^{\mathrm{d}}$ CNRS GEODE, Toulouse University Mirail, UMR 5602, F-31058 Toulouse, France \\ e School of Geography, University of Nottingham, Nottingham, NG7 2RD, UK \\ ${ }^{\mathrm{f}}$ Lancaster Environment Centre, Lancaster University, Bailrigg, Lancaster, LA1 4YQ UK \\ ${ }^{\mathrm{g}}$ School of Geosciences, University of Aberdeen, Aberdeen, AB24 3UF, UK
}

\section{A R T I C L E I N F O}

\section{Article history:}

Received 28 May 2013

Received in revised form

30 September 2013

Accepted 2 October 2013

Available online

\section{Keywords:}

Community mapping

Distance-weighted plant abundance

Pollen dispersal and deposition models

Pollen surface sample

Prentice-Sugita model of pollen dispersal

and deposition

Remote sensing data

Sutton model

Vegetation data processing

\begin{abstract}
A B S T R A C T
1. Quantitative reconstruction of past vegetation distribution and abundance from sedimentary pollen records provides an important baseline for understanding long term ecosystem dynamics and for the calibration of earth system process models such as regional-scale climate models, widely used to predict future environmental change. Most current approaches assume that the amount of pollen produced by each vegetation type, usually expressed as a relative pollen productivity term, is constant in space and time.

2. Estimates of relative pollen productivity can be extracted from extended R-value analysis (Parsons and Prentice, 1981) using comparisons between pollen assemblages deposited into sedimentary contexts, such as moss polsters, and measurements of the present day vegetation cover around the sampled location. Vegetation survey method has been shown to have a profound effect on estimates of model parameters (Bunting and Hjelle, 2010), therefore a standard method is an essential pre-requisite for testing some of the key assumptions of pollen-based reconstruction of past vegetation; such as the assumption that relative pollen productivity is effectively constant in space and time within a region or biome.

3. This paper systematically reviews the assumptions and methodology underlying current models of pollen dispersal and deposition, and thereby identifies the key characteristics of an effective vegetation survey method for estimating relative pollen productivity in a range of landscape contexts.

4. It then presents the methodology used in a current research project, developed during a practitioner workshop. The method selected is pragmatic, designed to be replicable by different research groups, usable in a wide range of habitats, and requiring minimum effort to collect adequate data for model calibration rather than representing some ideal or required approach. Using this common methodology will allow project members to collect multiple measurements of relative pollen productivity for major plant taxa from several northern European locations in order to test the assumption of uniformity of these values within the climatic range of the main taxa recorded in pollen records from the region.
\end{abstract}

(c) 2013 Elsevier Ltd. All rights reserved.

\section{Introduction}

Pollen analysis is one of the most common methods used to investigate past environments. Pollen and spores (palynomorphs)

\footnotetext{
* Corresponding author. Tel.: +44 1482466068.

E-mail address: m.j.bunting@hull.ac.uk (M.J. Bunting).
}

are widely dispersed as part of the plant reproductive cycle. Plant genetic material is encased within a tough cell wall with complex architecture and a high proportion of sporopollenin. This protective coat preserves well in a wide range of environments, enabling grains which are not successfully dispersed to a female flower or germination point to survive in the sedimentary archive. Palynomorphs are particularly well preserved in waterlogged environments such as lakes and bogs, and the progressive accumulation 
of sediment over time in these systems allows extraction of a series of pollen assemblages, from a core of sediment, which reflect changes in the vegetation cover of the wider landscape over time. However, translating these assemblages into quantitative estimates of vegetation is not a simple exercise; palynomorphs vary in size, shape and dispersibility, and differences in plant reproductive strategy and resource allocation lead to differences in the amount of pollen per unit plant produced by different taxa.

Three broad classes of approach to reconstructing past vegetation from pollen records can be identified: comparison with samples taken from analogous environments with known vegetation (e.g. Overpeck et al., 1985; Nielsen and Odgaard, 2004; Kuneš et al., 2008), biomisation (where pollen types are related to plant functional types, and proportions of functional types used to identify the most likely biome; e.g. Prentice et al., 1996; Prentice et al., 2000; $\mathrm{Ni}$ et al., 2010) and application of process-based models (e.g. Sugita, 2007a,b; Bunting and Middleton, 2009). Process-based model approaches take algebraic models of the relationship between pollen assemblages and producing vegetation (i.e. models of the taphonomic process linking them) and use them to translate pollen data into quantitative measures of vegetation cover. Two approaches using the same underlying models of pollen dispersal and deposition are currently being actively applied; the Landscape Reconstruction Algorithm (LRA; Sugita, 2007a,b) and the Multiple Scenario Approach (MSA; Bunting and Middleton, 2009). These are compared in outline in Fig. 1. Quantitative reconstructions of vegetation are important for investigation of a range of important research questions, particularly because they greatly facilitate the use of palaeoecological data to address issues raised within other academic disciplines such as ecology, climatology and archaeology. Gillson and Duffin (2007) used a process-based model to translate tree pollen percentages into past woody plant cover in savannah in southern Africa to inform identification of thresholds of concern for conservation monitoring in the region. The LANDCLIM project is using the LRA approach to reconstruct vegetation cover in northwest Europe on a $100 \mathrm{~km}$ grid basis as an input to regional climate models (e.g. Gaillard et al., 2010). In archaeological contexts, the approach allows different archaeologically derived hypotheses about landscape structure to be tested against extant pollen records (e.g. Caseldine et al., 2007; Tipping et al., 2009).

In this paper, we focus on the linear process-based model generally referred to as the Prentice-Sugita model, which underlies the LRA and is the primary model currently being used in the MSA. Linear models have a long history of use in the field (e.g. Davis, 1963, 2000; Andersen, 1970, 1973; Prentice, 1985, 1988; Sugita,
1993, 1994; Jackson, 1994). The model includes a taxon-specific measure of pollen production, which is usually estimated from empirical data. Pollen productivity $\left(\alpha_{i}\right)$ is a simple measure of the amount of pollen released for transport per unit area of pollenproducing vegetation (grains $\mathrm{m}^{-2} \mathrm{yr}^{-1}$ ). However, this is not simple to measure, and pollen productivity is usually estimated and expressed as a dimensionless ratio relative to a reference taxon (e.g. Davis, 1963; Andersen, 1970; Broström et al., 2008), termed the Relative Pollen Productivity (hereafter RPP). The reference taxon provides a benchmark for comparison between taxa and between datasets. Davis (1963) termed the ratio between the amount of pollen of one type present in a sample and the amount of plants producing that pollen type in the surrounding vegetation the Rvalue, and noted that whilst the absolute R-values calculated varied between sites, the ratio between the R-values of two taxa should be the same. By choosing a single taxon (the 'reference taxon') to always be the denominator in the calculation of this ratio, Andersen (1970) was able to present 'correction factors' for translating pollen percentages into estimates of vegetation abundance; for example, in natural-type forests in Denmark Quercus (oak) produced four times as much pollen per unit vegetation area than Fagus (beech) whilst Tilia (lime) produced only a quarter as much. The reference taxon chosen had to be present in both vegetation and pollen data at every site of interest, since a zero value for the denominator prevents calculation of the ratio.

Estimates of RPP are now derived using a computer-based iterative process of comparing the goodness of fit of a set of linear pollen-vegetation models against empirical datasets consisting of paired vegetation and pollen data for multiple taxa collected at tens of sites (discussed further in Section 2.1 below), rather than by simple ratio-taking, but a reference taxon still needs to be identified as a starting point for the iteration (for this taxon the RPP is set to a value of 1). In theory any taxon can serve as the reference taxon, but given the relatively small size of most empirical datasets reference taxon choice can affect the robustness of the iterative process and therefore of RPP estimates obtained. A good reference taxon is present in both pollen and vegetation data from as many of the sites sampled as possible, has a wide range of values of both parameters across the whole dataset, and is expected to have an intermediate absolute pollen production value. In most studies to date, the pollen taxon Poaceae has been used as the reference taxon (e.g. Hjelle, 1998; Broström et al., 2004; Nielsen and Odgaard, 2004; Räsänen et al., 2007; Soepboer et al., 2007; Mazier et al., 2008; von Stedingk et al., 2008; Poska et al., 2011; Abraham and Kozáková, 2012), although since this pollen taxon can

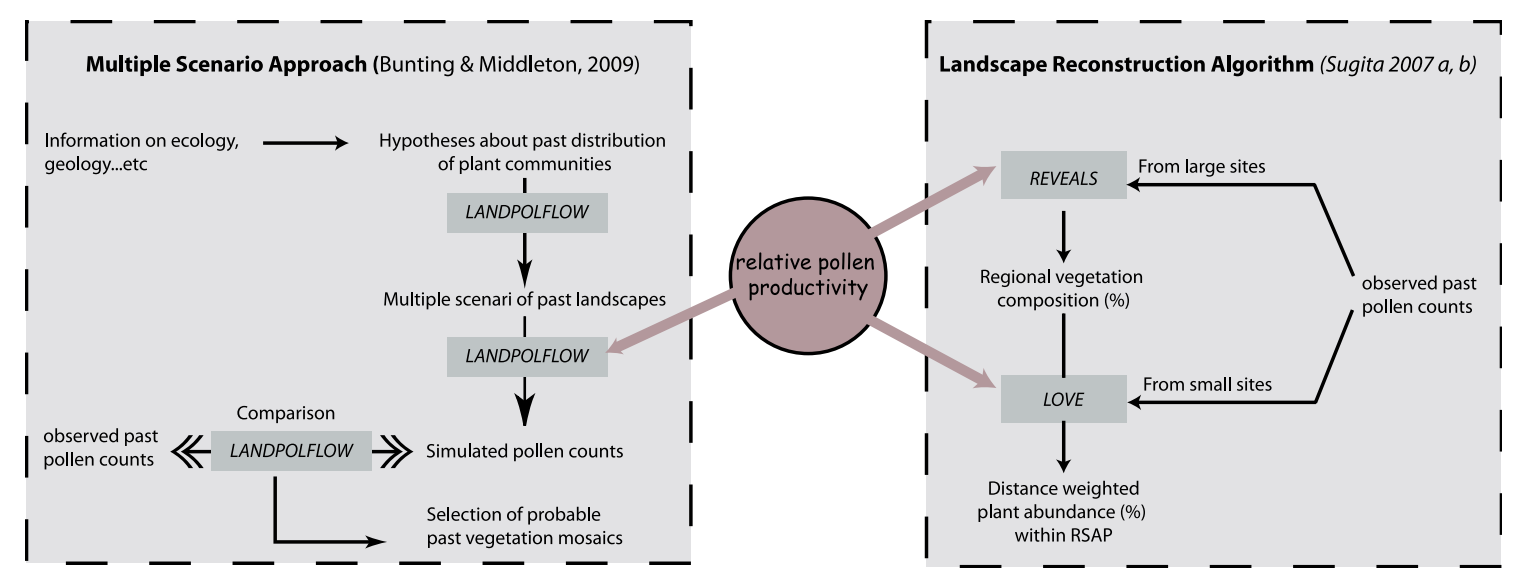

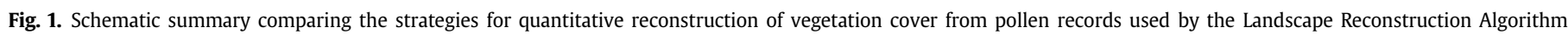
(Sugita, 2007a,b) and the Multiple Scenario Approach (Bunting and Middleton, 2009). 
originate from a wide range of plant species, it is likely that the same pollen type represents different plant species mixtures in the different studies making inter-study comparison less reliable.

Current reconstruction models (e.g. Sugita, 2007a, 2007b; Bunting and Middleton, 2009) assume that the pollen productivity of a given taxon relative to other taxa is effectively constant in space and time (that is, that the pollen production of all the taxa of interest responds to changes in climate or landscape structure in the same way). Considerable research effort has been invested in measuring Relative Pollen Productivity and multiple studies in northern Europe since 2001 have indicated wide variations in estimated values for common taxa (reviewed in Broström et al., 2008; Mazier et al. 2012a).

Bunting and Hjelle (2010) showed that one important element in the range of RPP estimates from different studies is variation in the methods of vegetation data collection. A number of other factors might explain differences in reported values. Taxonomic variation may occur within a pollen taxon; since not all pollen types can be identified to the specific level and some pollen taxa reflect the presence of multiple plant species (e.g. the pollen types Quercus, Rubiaceae or Poaceae). Thus the Rubiaceae pollen count could originate mainly from Galium saxatile in a moorland sample and from Galium boreale in a meadow sample, two species that have different growth habits and ecological requirements and responses (cf. Hjelle, 1998). Management of the local environment may alter pollen production. For example, grassland managed by grazing is likely to produce less Poaceae pollen than grassland managed as hay meadow, and the age structure of a managed forest affects the proportion of trees which have reached flowering age and thus produce pollen (Matthias et al., 2012). Differences in pollen production may also be driven by variations in local climate across Europe, either by direct climatic effects on flowering or through genotypic variation.

To test the assumption of constant RPP and, if RPPs do vary in space, assess the effects of the possible causal factors reviewed above, it is necessary to apply a standardised method for collection of both pollen and vegetation data. Pollen data may be collected from traps (e.g. Sugita et al., 2010a; Mazier et al., 2012b), moss polsters (e.g. Andersen, 1970; Hjelle, 1998; Broström et al., 2004; Bunting et al., 2005; Mazier et al., 2008; von Stedingk et al., 2008) or lake surface sediments (e.g. Soepboer et al., 2007; Poska et al., 2011; Hjelle and Sugita, 2012; Matthias et al., 2012). Collection of surrounding vegetation data will necessarily differ between the use of traps/moss polsters and lake sediments, and the methodology selected in the present paper is based on the use of surface moss samples for pollen collection. The vegetation methodology needs to be suitable for applying in multiple habitats with differing structure, and to maximise the data generated within a given amount of field time. A current research project (referred to as the 'Crackles Bequest Project') led from the University of Hull includes the aim of testing the constant RPP assumption by developing such a methodology and applying it to estimate values at multiple locations across Europe.

The vegetation survey method chosen needs to reflect a 'pollen's eye view' of vegetation, not a vegetation ecologist's view. Understanding what aspects of vegetation are 'seen' and recorded by the pollen assemblage is an important component in interpretation and reconstruction of vegetation mosaics. The pollen dispersal and deposition model used in this paper follows the assumptions from Prentice (1985) of pollen transport via wind in the zone just above the vegetation canopy (Tauber's canopy component; Tauber, 1967; see Fig. 2). Transfer of pollen from vegetation to the moving air stream occurs largely through eddies in the turbulent base of the air stream, and the further below the air stream/canopy interface a plant is, the less likely its pollen is to be incorporated into the transported assemblage.

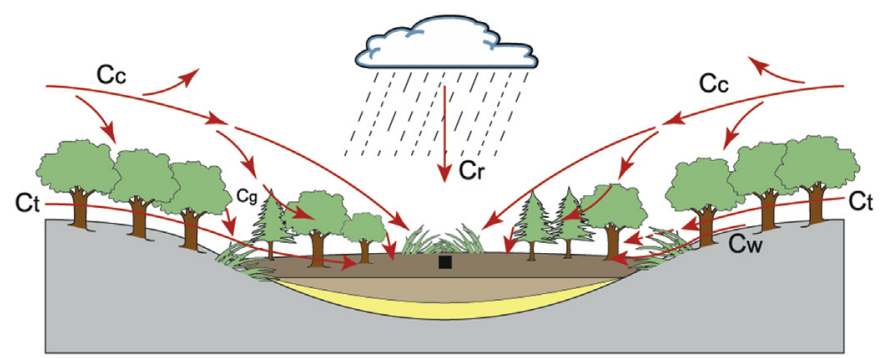

Fig. 2. The Tauber model of pollen taphonomy into a surface sample in a mire (equivalent to a moss in that the pollen once trapped by the vegetation remains static). $C_{r}=$ long-distance component delivered by precipitation, $C_{C}=$ canopy component, $C_{t}=$ trunk space component, $C_{\mathrm{w}}=$ runoff component, $C_{g}=$ gravity component (after Tauber, 1965, 1967; redrawn from Bunting, 2008).

The aims of this paper are:

a) to review the factors which affect the way in which the pollen signal at a single point represents the surrounding vegetation, including the properties of moss polsters as pollen traps, sample location, vegetation survey method and data handling

b) to present the method of vegetation recording adopted by the Crackles Bequest Project

\section{The Prentice-Sugita model of pollen dispersal and deposition}

The factors affecting the "pollen's eye view" of vegetation and thus the estimation of pollen productivity are closely linked to the pollen dispersal and deposition model used to link vegetation and pollen assemblage, therefore it is necessary to first consider the nature and assumptions of the model. All algebraic notations used in this section are defined in Table 1.

The Prentice-Sugita model of pollen dispersal and deposition (Prentice, 1985; Sugita, 1993, 2007a, 2007b; Bunting and Middleton, 2005, 2009) links the pollen signal and the vegetation via two main components, pollen production of the plant and pollen transport to the sampling point. At its simplest, the model can be written as:

$y_{i k}=\alpha_{i} \psi_{i k}$

where $\psi_{i k}$ is defined as:

Table 1

Algebraic notation used in mathematical expressions of the model of pollen dispersal and deposition.

\begin{tabular}{|c|c|}
\hline Notation & Definition \\
\hline$R$ & $\begin{array}{l}\text { The radius of the canopy opening in which the sample site is located } \\
\text { (i.e. the distance from the sampling point to the near edge of the } \\
\text { vegetation producing the pollen signal) }\end{array}$ \\
\hline $\mathrm{RPP}_{j}(i)$ & Pollen Productivity of type $i$ relative to the reference taxon $\mathrm{j}$ \\
\hline$y_{i k}$ & Pollen influx of taxon $i$ at a location $k$ \\
\hline$Z$ & Distance from sampling point to pollen-producing vegetation unit \\
\hline$\alpha_{i}$ & Pollen productivity of plants of taxon $i$ \\
\hline$\zeta_{\mathrm{k}}$ & Pollen source area for site $k$ \\
\hline$\psi_{i k}$ & $\begin{array}{l}\text { A dispersal term for transport of pollen of taxon } i \text { to site } k \text { from the } \\
\text { surrounding landscape (usually modelled as distance-weighted } \\
\text { plant abundance around site } k \text {, with the weighting term reflecting } \\
\text { the pollen dispersal of taxon } i \text { ) }\end{array}$ \\
\hline$\chi_{i k}(z)$ & $\begin{array}{l}\text { the contribution of taxon } i \text { to the pollen assemblage formed at site } k \\
\text { from plants located distance } z \text { from sampling location } k \text { (usually } \\
\text { expressed as a distance-weighted plant abundance measure) }\end{array}$ \\
\hline$\omega_{i}$ & Constant background pollen influx: $\alpha_{i} \int^{\infty} \chi_{i k}(z) \mathrm{d} z$ \\
\hline
\end{tabular}


$\psi_{i k}=\int_{R}^{\infty} \chi_{i k}(z) \mathrm{d} z$

This expression can be divided into two parts, one reflecting long-distance pollen transport (often referred to as the 'background pollen component', which is essentially uniform within a region) and one reflecting the unique contribution of the vegetation closer to site $k$, giving:

$\psi_{i k}=\int_{R}^{\zeta} \chi_{i k}(z) \mathrm{d} z+\int_{\zeta}^{\infty} \chi_{i k}(z) \mathrm{d} z$

Equation (1), the model for pollen influx at site $k$, can now be written as:

$y_{i k}=\alpha_{i}\left(\int_{R}^{\zeta} \chi_{i k}(z) \mathrm{d} z+\int_{\zeta}^{\infty} \chi_{i k}(z) \mathrm{d} z\right)$

and writing the constant background term $\alpha_{i} \int_{\zeta}^{\infty} \chi_{i k}(z) \mathrm{d} z$ as $\omega_{i}$ gives

$y_{i k}=\alpha_{i} \int_{R}^{\zeta} \chi_{i k}(z) \mathrm{d} z+\omega_{i}$

The distance at which this division between background and local components is made defines a 'pollen source area'. In the Prentice-Sugita model, the distance is termed the Relevant Source Area of Pollen (RSAP), and defined as the distance beyond which adding more vegetation survey data to the $\chi_{i k}(z)$ term does not improve the goodness of fit of the model to a dataset of pollen counts and vegetation abundance from sample points collected within a single biogeographic region (Sugita, 1994). The RSAP can be understood as a geographically defined area close to site $k$ where changes in the vegetation composition and position relative to the sampling point are recorded by changes in the pollen assemblage. The background pollen component, the signal coming from the landscape beyond that source area, reflects the overall vegetation composition of the region and only changes when that larger-scale area undergoes a change in composition.

\subsection{Model calibration}

Two taxon-specific parameters are required to use the PrenticeSugita model for reconstruction of past vegetation from the pollen record, $\alpha_{i}$ and $\omega_{i}$ (see Table 1 for definitions of algebraic notation). Since $\omega_{i}$ reflects the vegetation composition of the wider landscape it varies in both space and time, and is estimated as part of the reconstruction process. Relative pollen productivity, on the other hand, is generally assumed to be constant in space and time and, therefore, can be estimated empirically from contemporary studies of pollen-vegetation datasets. This paper focuses on empirical estimation of the dimensionless relative pollen productivity ratio, $\alpha i$ or $\operatorname{RPP}_{j}(i)$ (the pollen productivity of taxon $i$ relative to taxon $j$ ). If distance-weighting of vegetation data is carried out using the Sutton model of particle transport (the Prentice-Sugita approach) a third parameter, pollen fallspeed, is also required. This parameter can be obtained via direct measurement (see review in Jackson and Lyford, 1999) or by estimation based on grain measurements using Stoke's law (see e.g. Broström et al., 2004).

If pollen and vegetation data are both measured in absolute units (e.g. annual pollen influx, biomass), then $\alpha_{i}$ can be calculated directly using linear regression analysis on the data for each taxon
(Sugita et al., 2010a; Mazier et al., 2012b). However, in many cases at least one of these parameters is measured in relative units and values are only available in percentages. Data values for individual taxa are no longer independent and, therefore, nor are the parameters $\alpha_{i}$ (even if expressed as RPP) and $\omega_{i}$.

The Extended R-Value or ERV analysis (Parsons and Prentice, 1981; Prentice and Parsons, 1983) approach offers a means of determining RPP and $\omega_{i}$ from interdependent percentage data using the maximum likelihood method (Fisher, 1912) to find the set of parameter estimates which give the best fit between corrected values of a dataset of pollen-vegetation data pairs from multiple locations. Although ERV analysis can be carried out on singledistance vegetation survey data (e.g. Hjelle, 1998), if the single distance is substantially less than the radius of the pollen source area, the estimates of RPP can be misleading. The assumption that all plants within that area contribute equally to the pollen influx at the sampling point is weak and distance-weighted plant abundance is recommended. Most recent studies use vegetation survey data from multiple distances (e.g. Broström et al., 2008) where ERV analysis is applied using cumulated distance-weighted plant abundance at increasing distances from the pollen sample points. Estimates of the model parameters, RPP and the background pollen term, are taken from the values at, or an average of values at distances greater than, the Relevant Source Area of Pollen (RSAP).

\subsection{Location of the sample point}

The assumptions of the model have important consequences for the selection of sampling sites. The ERV method assumes that the background pollen component $\omega_{i}$ is the same for all the samples included in the analysis, therefore a set of sample points all need to be collected within an essentially homogenous landscape region. However, the definition of a homogenous region for purposes of defining background pollen remains unclear in the 'real world' where ecotones tend to be gradual, geology and topography variable, and landscape management imposes geometric divisions on some landscapes. In theory the maximum spatial extent of the regional vegetation from the centre of the site $\left(Z_{\max }\right)$ can be 50 $400 \mathrm{~km}$ (Sugita, 2007a). For the purposes of this work, we propose assuming that any area delimited by a $50-100 \mathrm{~km}$ radius can be considered to have a uniform background pollen rain with reference to the ERV approach. This assumption has effectively also been made previously (Hellman et al., 2008) and more recently by the LANDCLIM project (Gaillard et al., 2010). Mazier et al. (2012a) showed that different values of $Z_{\max }$ (i.e. 50,100 and $200 \mathrm{~km}$ ) did not affect the vegetation reconstruction obtained from fossil pollen data via the LRA approach.

The models of pollen dispersal and deposition used in the ERV approach currently assume that the landscape is flat both by making no allowance for topographic effects on air flow or pollen deposition from the air stream and by ignoring the possible role of overland water flow as a mechanism of pollen transport (see Tauber, 1965). Locations on steep slopes, especially where a distinctive habitat such as woodland is distributed on the sides of a river gorge or similar ravine, are therefore to be avoided since such topographies are expected to substantially affect air flow and hence pollen flux.

Broström et al. (2005) demonstrate the importance of random sample point location for studies using the ERV-approach, especially for the estimation of RSAP, but truly random sample positioning is often not practicable. For example, in managed landscapes, it may not be possible to get permission to access some locations (e.g. disturbance-sensitive crops, private gardens), and others may not be suitable for any kind of pollen sampling (e.g. a parking area). 
In order to reduce the impact of seasonal and annual variability in pollen production, both pollen traps and vegetation data need to reflect a relatively long time period. As discussed below, the temporal resolution of the pollen assemblages is unresolved for sample types other than pollen traps. Rapidly changing landscapes clearly present a particular problem here. Whilst a single vegetation survey of a woodland can be considered to be a reasonable estimate of the vegetation present over the last 5-10 years, rapid turnover and rotation of plant crops makes a single visit estimate unrepresentative. Information from the land owner/manager can elucidate the basic history, but details of vegetation composition in previous years are generally not obtainable. Weed floras are particularly dynamic, especially near field margins, where changes in management of the field can change which elements flower and produce dispersible pollen. The presence of volunteers from previous crops can also complicate the situation especially for crops such as oil seed rape which are palynologically equivalent to 'weed' species of interest.

For the Crackles Bequest Project, three cultural habitat types containing taxa which are well-represented in Holocene pollen diagrams and therefore important in palaeoenvironmental reconstruction were selected; meadows, heaths and woodlands. Sample location is therefore broadly determined by the location of surviving fragments of these traditional landscapes; this is not a random sampling process, but ensured that a range of traditional human-mediated landscape types were sampled within a given study area. Within each identified fragment, constraints on possible sample position were set wherever possible ${ }^{1}$ by establishing a 'buffer zone' of 50-100 m around the edge of the fragment to avoid any problems with 'edge effects' (see Section 4.5 below) and only sampling in the inner area. Within this inner area, a random sampling strategy was carried out.

It is also important to avoid spatial autocorrelation between closely positioned sampling points, or at least reduce the risk of autocorrelation problems in the analysis; it is not entirely clear over what distance autocorrelation occurs in pollen assemblages, how it varies with vegetation structure and with RSAP, or how substantial an effect it is likely to have (Twiddle et al., 2012). The minimum recommended buffer between points is one RSAP distance (Shinya Sugita, personal communication), and although published estimates of RSAP vary (between 50 and $150 \mathrm{~m}$ for woodland moss samples - Sugita, 1994; Calcote, 1995; $400 \mathrm{~m}$ or so for grazed pastures - Broström et al., 2004; as little as $4-10 \mathrm{~m}$ for heaths Bunting and Hjelle, 2010), $200 \mathrm{~m}$ was considered an acceptable minimum distance and was adopted in the Crackles Bequest Project. Ideally only one sampling point would be collected per fragment, but this was not always possible within a study region.

\subsection{Moss polsters as pollen assemblage traps}

Ideally, the pollen assemblage would represent an average of about 10 years pollen production, and be associated with records of the vegetation over that period, in order to avoid interannual variations in pollen production of different species. These variations are known from pollen trap studies to be substantial; partly related to variations in seasonal temperature and precipitation (e.g Andersen, 1973; Hicks, 2001; Nielsen et al., 2010). However, carrying out trapping for 10-year time periods in multiple locations is time-consuming and challenging. Moss polsters may preserve and integrate several years of pollen rain (see e.g. Andersen, 1970; Bradshaw, 1981; Caseldine, 1981; Mulder and Janssen, 1998,

\footnotetext{
${ }^{1}$ Buffer zones could not always be placed around areas of meadow, which often survive as narrow, elongate features reflecting local hydrology and landscape history. In these cases the sample was placed centrally within the meadow.
}

1999), thus partly avoiding the high interannual variations; although some studies indicate that the amount of pollen in a moss polster represents a little more than a year's production (Räsänen et al., 2004). Trapping properties are also likely to vary with the growth form of the moss selected. However, mosses are believed to give reliable estimates of the smoothed pollen signal when data are expressed as percentages (Boyd, 1986).

A comparison of the pollen trapping characteristics of moss polsters, pollen traps and lake sediments showed that they reflected differences in vegetation types in similar ways, but that pollen traps tended to be biased towards lower tree pollen and higher NAP percentages than the other types, and Pinus pollen is captured more effectively by moss polsters than by pollen traps (Lisitsyna et al., 2012). Most work to date has used moss polsters as the pollen trap. In the absence of moss polsters, surface soil samples have been used, but there is little work on their representativeness.

Moss polster surface samples are collected in different ways in different studies (see Table 2), for example as a single moss sample at the centre of the surveyed area (e.g. Bunting and Hjelle, 2010) or as multiple mosses from within a small defined area which are amalgamated into one sample (e.g. Broström et al., 2004). The single-sample method is a better replicate of the assemblages contained within a sediment core. However, the relatively short temporal resolution of a moss sample compared to $1 \mathrm{~cm}$ thickness of peat or lake sediment may make it an imperfect analogue even when the sample is taken from the same type of environment as would be cored. The sample is also vulnerable to the effects of pollen addition through other routes than aerial deposition such as from insects or an anther fall, which can cause spikes in the percentage of one taxon. Where the pollen taxon involved is not important to the central analysis (e.g. an insect-pollinated taxon unlikely to be included in the final estimation of RPP), the taxon can be excluded during counting; however, this sort of addition can occur with key taxa which cannot sensibly be excluded from the sum, particularly those such as Poaceae or Calluna vulgaris which may grow close to the sampling point. Spotting an affected assemblage is quite probable (although not certain) during data examination, but discarding the sample from analysis also discards the time spent on vegetation survey. The multiple-amalgamate method effectively smoothes over spikes in individual taxa, reducing the risk of sample removal, ${ }^{2}$ but it does not eliminate them. Potentially this leads to either data loss or to misleading data. The best approach is probably, where feasible, to collect multiple samples from within less than $1 \mathrm{~m}$ of each other into separate bags, initially processing and counting one, but having the other(s) available as alternates in case a 'spike' is found, the assemblage as a whole seems to be an outlier, or pollen survival is poor. In the Crackles Bequest Project protocol, a single polster is collected and defines the central point of the vegetation survey.

\subsection{Field method for vegetation survey}

A range of survey methods have been used in past studies to collect vegetation data (see Table 2). These include: rooted frequency within square-metre plots (Hjelle, 1998); cover estimates within $0.5 \mathrm{~m}$ radius plots at different distances from the centre point (Bunting, 2003); cover estimates collected from concentric rings around the pollen sampling point (Broström et al., 2004; Räsänen et al., 2007; Mazier et al., 2008); and mapping

\footnotetext{
2 and incidentally means that the area within which the mosses were collected can be considered as a small basin, which makes the practice of setting basin area to $0.5 \mathrm{~m}$ radius in order to enable ERV-software to calculate some distance-weighting models less problematic than for a single sample (Mazier et al., 2008).
} 
Summary of field methodologies adopted by some previous studies of relative pollen productivity undertaken using the Extended R-value method (i.e. collecting vegetation data from multiple distances) with moss polsters used

\begin{tabular}{|c|c|c|c|c|c|c|c|c|c|c|c|}
\hline \multirow[t]{2}{*}{ Study area } & \multirow[t]{2}{*}{ Authors } & \multirow[t]{2}{*}{ Lat. } & \multirow[t]{2}{*}{ Long. } & \multirow{2}{*}{$\begin{array}{l}\text { Major vegetation } \\
\text { types sampled }\end{array}$} & \multirow[t]{2}{*}{ Pollen trap } & \multicolumn{3}{|c|}{ Vegetation survey radius (m) } & \multicolumn{3}{|c|}{ Vegetation survey method } \\
\hline & & & & & & Zone A & Zone B & Zone C & Zone A & Zone B & Zone C \\
\hline Northern New York, USA & $\begin{array}{l}\text { Jackson and Kearsley } \\
\text { (1998) }\end{array}$ & $44^{\circ} 6^{\prime} \mathrm{N}$ & $73^{\circ} 55^{\prime} \mathrm{W}$ & $\begin{array}{l}\text { Mixed broad- } \\
\text { leaved and } \\
\text { coniferous } \\
\text { woodland }\end{array}$ & $\begin{array}{l}\text { Single moss polster } \\
\text { from centre of } \\
\text { survey area }\end{array}$ & 20 & 120 & - & $\begin{array}{l}\text { Diameter at breast } \\
\text { height measured } \\
\text { for all trees }>10 \mathrm{~cm} \\
\text { diameter and used } \\
\text { to calculate } \\
\text { absolute and } \\
\text { percentage basal } \\
\text { area for each tree } \\
\text { taxon. }\end{array}$ & $\begin{array}{l}\text { Estimates of forest } \\
\text { composition and } \\
\text { basal area made } \\
\text { from } 85 \text { Bitterlich } \\
\text { counts in a grid } \\
\text { array, with grid } \\
\text { density decreasing } \\
\text { with distance from } \\
\text { plot centre. }\end{array}$ & - \\
\hline Western Norway & Hjelle (1998) & $61^{\circ} \mathrm{N}$ & $5^{\circ} 30^{\prime} \mathrm{E}$ & $\begin{array}{l}\text { Coastal heathland, } \\
\text { grazed and mown } \\
\text { meadows }\end{array}$ & $\begin{array}{l}\text { Single moss polster } \\
\text { from centre of each } \\
\text { quadrat; analysed } \\
\text { individually }\end{array}$ & 0.5 & - & - & $\begin{array}{l}\text { Rooted frequency } \\
\text { in five } 1 \mathrm{~m}^{2} \\
\text { quadrats randomly } \\
\text { placed within a } \\
10 \mathrm{~m} \times 10 \mathrm{~m} \\
\text { quadrat. Pollen } \\
\text { counted from all } \\
\text { quadrats } \\
\text { individually. }\end{array}$ & - & - \\
\hline Southern Sweden & Sugita et al. (1999) & $55-59^{\circ} \mathrm{N}$ & $12-17^{\circ} \mathrm{E}$ & $\begin{array}{l}\text { Broad-leaved } \\
\text { woodland, grazed } \\
\text { and mown } \\
\text { meadows }\end{array}$ & $\begin{array}{l}\text { Ten moss polsters } \\
\text { from } 10 \mathrm{~m}^{2} \\
\text { quadrat; } \\
\text { amalgamated }\end{array}$ & 5 & 50 & - & $\begin{array}{l}\text { Percentage cover of } \\
\text { inner } 10 \mathrm{~m}^{2} \\
\text { quadrat. }\end{array}$ & $\begin{array}{l}\text { Percentage cover of } \\
\text { entire } 100 \mathrm{~m}^{2} \\
\text { quadrat. }\end{array}$ & - \\
\hline Southern Sweden & Broström et al. (2004) & $55-59^{\circ} \mathrm{N}$ & $12-17^{\circ} \mathrm{E}$ & $\begin{array}{l}\text { Grazed and mown } \\
\text { meadows }\end{array}$ & $\begin{array}{l}\text { Ten moss polsters } \\
\text { from within } 0.5 \mathrm{~m} \\
\text { radius at centre of } \\
\text { survey area; } \\
\text { amalgamated }\end{array}$ & 10 & 100 & 1500 & $\begin{array}{l}\text { Percentage cover } \\
\text { recorded in } \\
\text { concentric } 1 \mathrm{~m} \\
\text { rings. }\end{array}$ & $\begin{array}{l}\text { Communities } \\
\text { mapped and } \\
\text { species } \\
\text { compositions } \\
\text { recorded in the } \\
\text { field. }\end{array}$ & $\begin{array}{l}\text { Communities } \\
\text { mapped using } \\
\text { aerial photographs. }\end{array}$ \\
\hline Eastern England & Bunting et al. (2005) & $52^{\circ} 32^{\prime} \mathrm{N}$ & $1^{\circ} 14^{\prime} \mathrm{E}$ & $\begin{array}{l}\text { Broad-leaved } \\
\text { woodland }\end{array}$ & $\begin{array}{l}\text { Single moss polster } \\
\text { within } 10 \mathrm{~m}^{2} \\
\text { sampling area }\end{array}$ & 5 & 130 & - & $2 \mathrm{~m}$ radius relevé. & $\begin{array}{l}\text { Composition } \\
\text { derived from TIN } \\
\text { contour map of } \\
\text { vegetation cover } \\
\text { (derived from all } \\
\text { sample points) in } \\
\text { combination with } \\
\text { aerial photographs. }\end{array}$ & - \\
\hline Northern Finland & Räsänen et al. (2007) & $68-69^{\circ} \mathrm{N}$ & $29-29^{\circ} \mathrm{E}$ & $\begin{array}{l}\text { Pine woodland, } \\
\text { birch woodland, } \\
\text { mires }\end{array}$ & $\begin{array}{l}\text { Single moss polster } \\
\text { from centre of } \\
\text { survey area }\end{array}$ & 10.5 & - & 10,000 & $\begin{array}{l}\text { Percentage cover } \\
\text { recorded in } \\
\text { concentric } 1 \mathrm{~m} \\
\text { rings for each } \\
\text { quadrant of the } \\
\text { circle. Percentage } \\
\text { covers for the four } \\
\text { quadrants were } \\
\text { averaged for each } \\
1 \mathrm{~m} \text { ring. }\end{array}$ & - & $\begin{array}{l}\text { Communities } \\
\text { mapped using } \\
\text { satellite images, } \\
\text { topographical maps } \\
\text { and National Forest } \\
\text { Inventory data. }\end{array}$ \\
\hline Swiss Jura & Mazier et al. (2008) & $46^{\circ} 32^{\prime} \mathrm{N}$ & $6^{\circ} 12^{\prime} \mathrm{E}$ & Pasture woodland & $\begin{array}{l}\text { Several moss } \\
\text { polsters from } \\
\text { within } 0.5 \mathrm{~m} \text { radius } \\
\text { at centre of survey } \\
\text { area; amalgamated }\end{array}$ & 10 & 100 & 1500 & $\begin{array}{l}\text { Percentage cover } \\
\text { recorded in } \\
\text { concentric } 1 \mathrm{~m} \\
\text { rings for each } \\
\text { quadrant of the } \\
\text { circle. Percentage } \\
\text { covers for the four } \\
\text { quadrants were }\end{array}$ & $\begin{array}{l}\text { Herb composition } \\
\text { for each } \\
\text { community } \\
\text { extracted from pre- } \\
\text { existing vegetation } \\
\text { maps. Percentage } \\
\text { cover of tree } \\
\text { crowns recorded }\end{array}$ & $\begin{array}{l}\text { Communities } \\
\text { mapped using } \\
\text { aerial photographs. } \\
\text { Species } \\
\text { compositions for } \\
\text { communities not } \\
\text { encountered in } \\
\text { Zone A or B were }\end{array}$ \\
\hline
\end{tabular}




\section{survey area}

Abrah (2012) $50^{\circ} \mathrm{N}$

$14-15^{\circ} \mathrm{E}$ Coniferous

(Czech Rep woodland, broad-

leaved woodland,

sites, alluvial

vegetation averaged for each $1 \mathrm{~m}$ ring.

Single moss polster -

from centre of

survey area

Single moss polster 10
from centre of
survey area

Four $1 \mathrm{~m}^{2}$ quadrats used to record
100

2000

Four $0.5 \mathrm{~m}^{2}$

quadrats (one at

each cardinal point)

cover at $1 \mathrm{~m}$ radi

Beyond this

distance,

communities

mapped and

species

compositions

recorded in the

field using an

average of four

quadrats.

Three method

compared:

1) Rooted

frequency within

$1 \mathrm{~m}^{2}$ quadrats

placed over the

central point and in

four cardinal

directions

contiguous with

the central quadrat

frame.

within $1 \mathrm{~m}^{2}$

quadrats located at

a range of distances

along the four

cardinal axes.

3) Percentage cover

recorded in

concentric $1 \mathrm{~m}$

rings.

-
2) Percentage cover

within a $1 \mathrm{~m}$ wide band along 12

either recorded in the field or

transects from the forest inventory

pollen sampling data.

point.

As for Zone A. Communities

Forest cover mapped using

recorded by aerial photographs

estimating cover of and species

compositions

branches for each assigned on the

tree taxon in $1 \mathrm{~m}$ basis of the field

survey.

survey.

Z

Communities Communities extracted from extracted from existing vegetation existing vegetation maps. Species maps. Species compositions for compositions for communities not encountered in Zone A were Zone A were recorded during a recorded during a second field visit. second field visit.

Communities mapped using aerial photographs aerial photographs and field mapping. Species

compositions recorded in the field using percentage cover. Communities

Beyond this species

coverage were estimated using communities were taken from four $2 \mathrm{~m}$ aerial photographs 


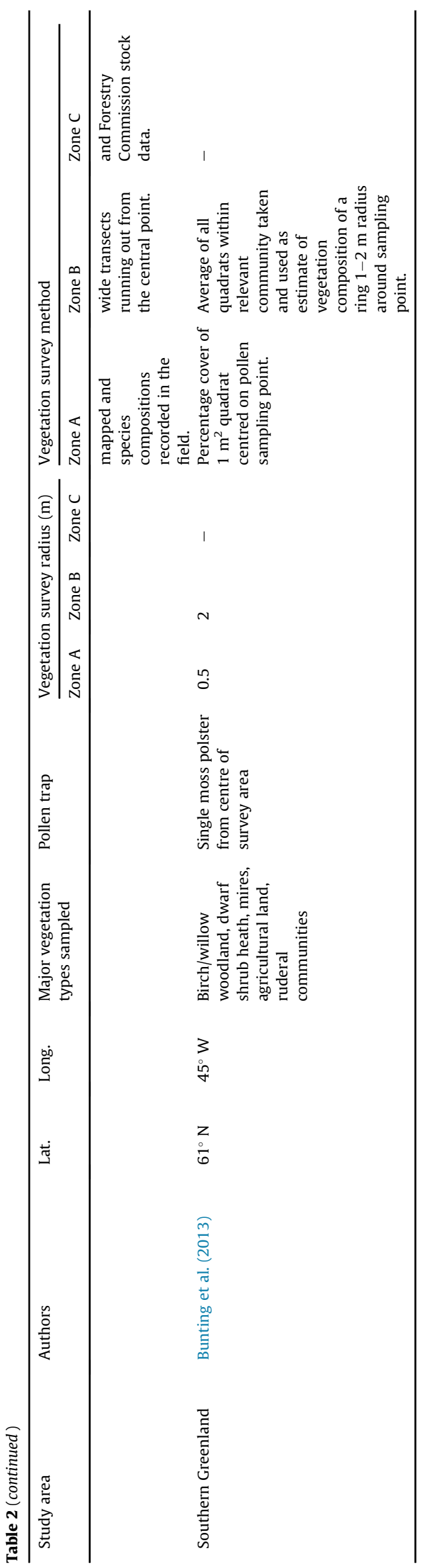

communities in a defined radius circle, characterising vegetation cover using randomly placed quadrats, then extracting cover estimates for concentric rings using GIS (von Stedingk et al., 2008). The effect of three of these methods on RPP estimates was explored by Bunting and Hjelle (2010), who surveyed the area around a set of moss polsters repeatedly using different methods during a single field week, and estimated RPP using $C$. vulgaris as the reference taxon. They found marked differences between the different vegetation survey methods; for example, the RPP of Potentilla-type relative to $C$. vulgaris was around 0.5 using the rooted frequency method and around 2.5 using the visual estimate of cover method, reflecting the growth habit of the main plant species producing this pollen type within the field area (Potentilla erecta, which occurs as many small plants scattered throughout all but the wettest parts of the topography). A common feature of previous methods is varying the intensity of survey by combining detailed field recording close to the sampling point with more general mapping and remotesensed data at greater distances (Broström et al., 2004; Räsänen et al., 2007; Mazier et al., 2008; von Stedingk et al., 2008; Twiddle et al., 2012), since the model assumes that the more distant a plant is from the sampling point the less likely it is to make a significant contribution to the pollen assemblage.

\subsubsection{Principles underlying choice of vegetation survey method}

The vegetation survey method selected is intended to best match the 'pollen's eye view' of the vegetation and therefore needs to reflect the assumptions about that view made by the models being calibrated, as well as representing the minimum necessary survey effort. Based on the above review, an effective survey method needs to:

1. Be able to reflect the Prentice-Sugita distance-weighting method assumption that the dominant mode of pollen transport is in the air stream associated with the upper layer of the vegetation canopy.

2. Reflect the model assumption that vegetation closest to the sampling point makes the largest contribution to the pollen signal and the relative importance of each pollen source (e.g. unit area of vegetation) decreases with distance from the sampling point.

3. Produce a calibration dataset which extends to or beyond the RSAP of the system being studied.

4. Focus on producing good estimates of the abundance of the major taxa (the producers of the pollen types which are the major components of current and past pollen rain in the study region) rather than recording every species present.

\subsubsection{Upper canopy layer}

Pollen transport to the sampling site was divided into different categories by Tauber (1965, 1967; see Fig. 2), and Prentice (1985) argued that the above-canopy flux was the dominant mode of transport into mires, which he conceived as openings in a forested canopy for the purposes of model development. The assumption of dominance of pollen transport in the upper canopy boundary layer is supported by some empirical evidence; including the known rapid diminution of wind speed with movement through the upper canopy and trapping studies tracing isotopically labelled pollen grains (Raynor et al., 1974). This model has been extended to a wide variety of contexts, with apparent success, but becomes less tenable as the sampled situation moves further from the assumed situation of a circular opening free of pollen-producing plants in a generally closed canopy of uniform height. However, it will be used as a framing device in the absence of an alternative which suits all environments likely to be encountered. 
This assumption implies that data collection effort needs to focus on the upper canopy layer. A method based on percentage cover in vertical projection seems most closely allied to the transport model, and use of rooted frequency methods in particular are ruled out since sprawling species making a large canopy contribution relative to their basal stem distribution are underrepresented by those methods. Percentage cover by vertical projection is also a practical method for field estimates of tree cover and is most readily combined with aerial photograph analyses and other remote-sensed data, which are often used to extend the area of mapped vegetation beyond the fieldwork limits to achieve objective 3 .

In treeless vegetation this methodological constraint is relatively easy to put into practice, but it is harder in woodland areas, especially when the sample is not located in an obvious clearing. Pollen types with potential understorey sources are recorded in the pollen assemblage and are often of interest (e.g. grasses) to the wider study, and whilst quite a few studies have used moss polsters collected from very small gaps or under the woodland canopy (e.g. Calcote, 1995; Sugita et al., 2010b) or combine samples from under closed canopies with those from open areas (e.g. von Stedingk et al., 2008; Mazier et al., 2008) and the data appear to conform to the model, it is not clear how valid the assumption is. How large a gap is needed for pollen to be predominantly from the above-canopy air flow has not been investigated, although Caseldine's (1981) study of a wood-fringed mire suggested that there is a sizable 'edge zone' where pollen assemblages show reduced amounts of 'beyond the woodland' pollen types. In order to accommodate this uncertainty, a suitable field method should include some recording of the understorey vegetation and the 'gappiness' of the canopy within woodlands, in order to provide empirical data which will still have value if the assumption that the only relevant vegetation layer is the upper canopy is found to be inappropriate.

\subsubsection{Distance-dependent contribution to pollen loading}

Pollen dispersal from the pollen source is modelled as a leptokurtic dispersal curve (e.g. Prentice, 1985). This is handled in the ring source approach (Sugita, 1994) by taking the percentage of each palynological-equivalent plant taxon in a series of concentric rings centred on the sample point and applying a weighting function. Nearly all published work uses one or more of three weighting options, a taxon-specific model of particle dispersal from a surfacelevel source based on empirical experimentation often referred to as the Sutton distance weighting function (Sutton, 1953; Prentice, $1985)$, inverse distance $\left(z^{-1}\right)$ or inverse distance squared $\left(z^{-2}\right)$. Choice of ring width and distance-weighting model clearly affect the distance-weighted plant abundance data produced and the results of ERV analysis, but identifying the criteria for preferring one method over others is not simple. Previous studies find different methods yielding the 'best' results for different datasets, as measured by the likelihood function scores and stability of ERV output. Fig. 3a shows plots illustrating the distance-weighting functions most commonly used. It illustrates that inverse distance and the taxon-specific distance weighting curves have a similar shape, whilst the inverse distance squared weighting method places greater emphasis on vegetation data collected from within a few metres of the sampling point, with a more rapid decline in relative contribution with increasing distance than the other two models. Fig. 3b shows how choice of ring width, which affects data collection strategy, also changes the relative importance of vegetation at different distances, especially in the innermost survey area. Although different distance weighting methods are found to affect RPP estimates (e.g. Broström et al., 2004; Mazier et al., 2008; Bunting and Hjelle, 2010; Poska et al., 2011), little systematic empirical study has been carried out to show how these
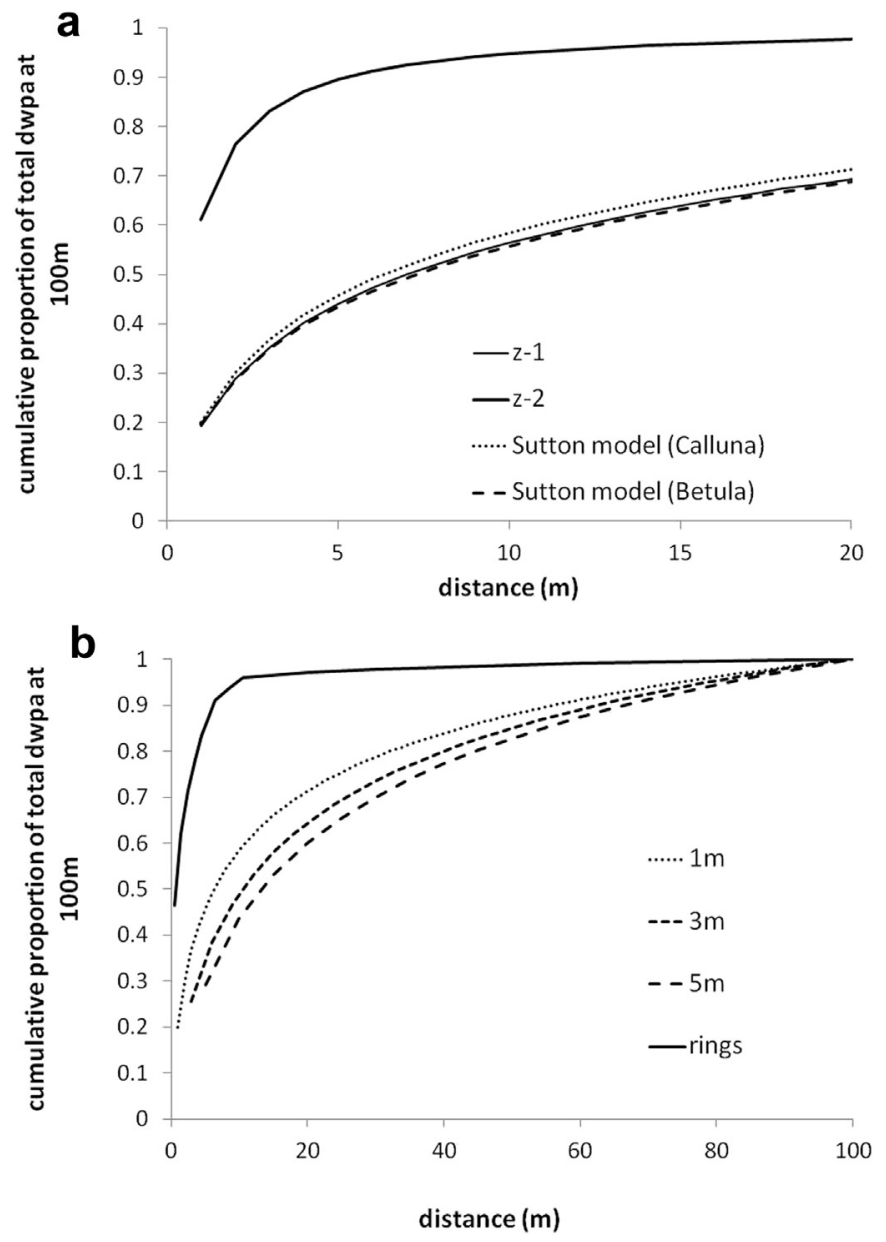

Fig. 3. Results of simulations exploring the effects of variation in weighting model and ring width on distance-weighted plant abundance data a) shows the effect of weighting model choice on the proportion of distance-weighted plant abundance at $100 \mathrm{~m}$ accumulated at different distances (using $1 \mathrm{~m}$ wide rings in all cases). b) shows the effect of variation in ring width on the proportion of the total distance-weighted plant abundance at $100 \mathrm{~m}$ which is contributed by different distances using the Sutton model at $1 \mathrm{~m}$ intervals, $3 \mathrm{~m}, 5 \mathrm{~m}$ and 'rings' method (an inner ring of $0.5 \mathrm{~m}$ radius, $1 \mathrm{~m}$ radius rings to $6.5 \mathrm{~m}, 2 \mathrm{~m}$ rings to $10.5 \mathrm{~m}$ and then $10 \mathrm{~m}$ rings beyond that; Broström et al., 2004 and others).

methodological choices affect estimated values of RPP, or investigate how the different models relate to pollen movement in the landscape. In the absence of such empirical evidence, the Crackles Bequest Project strategy needs to collect data in a format which can be analysed using different ring-width and weighting strategies at a future date.

The assumed leptokurtic decline in pollen contribution with distance also supports the preferred choice of a nested structure for vegetation data collection, with rapid reduction in effort invested with increasing distance. Choice of nesting distances is fairly arbitrary; although standard approaches tend towards a decimal scaling scheme, this is apparently driven by convenience rather than any clear empirical basis. Published empirical estimates of RSAP of less than $10 \mathrm{~m}$ for fine-grained communities such as heathland and grassland (e.g. Bunting and Hjelle, 2010), of around $100 \mathrm{~m}$ for samples under woodland canopies (e.g. Calcote, 1995; Bunting et al., 2005), and of $400 \mathrm{~m}+$ for mosaic landscapes (e.g. Broström et al., 2005), offer some support for the choice of nesting distances (see Broström et al., 2008), which for moss polster pollen assemblage studies typically move from detailed recording to community mapping at about $10 \mathrm{~m}$ and from field mapping to 
remote sensed maps at about $100 \mathrm{~m}$. The strategy adopted is summarised in Fig. 4.

\subsubsection{Major taxon focus}

The focus on the major taxa making up the bulk of the pollen sum for reconstruction using quantified methods, and the known problems of wide confidence limits on counts of minor taxa (Maher, 1972) which often are entirely entomophilous, suggests that a sampling approach is sufficient with no need for complete recording. This is not to say that the minor taxa are not interesting, but their value is largely as indicator taxa rather than as sources of reconstruction of the broad structure of the vegetation composition (e.g. providing information about intensity and moisture levels in pasture areas, not about the proportion of the landscape dominated by grassy communities; see Behre, 1981; Gaillard et al., 1994; Hjelle, 1998, 1999a, b; Mazier et al., 2006, 2009). The major taxa are defined as the dominant taxa in recent and past vegetation/landscape.

\section{The Crackles Bequest Project vegetation survey methodology}

The detailed vegetation survey protocol developed on the basis of the constraints considered above is presented as Fig. 5. Recording sheets are presented in the Appendix. Zone A $(0-10 \mathrm{~m})$ is recorded using a standard array of 21 quadrats (Fig. 6) centred on the moss polster sampled. In woodlands, the canopy above each quadrat is recorded as well as the ground flora. Vegetation communities in Zone B (10-100 m) are mapped in the field and their composition recorded using standard methods for open, semi-open and treedominated community stands and for linear features such as ditches or hedgerows (see Appendix).

To test whether the quadrat array effectively sampled zone A, where methodological differences are expected to have the strongest effect on the distance-weighted plant abundance values used to estimate RPP, data was collected in two different habitats (maritime heath and grazed grassland) applying two different methods of vegetation survey around the same central point (Fig. 6). Sampling was carried out using visual estimation of cover in the standard array of $1 \mathrm{~m} \times 1 \mathrm{~m}$ quadrats and full recording carried out by estimating vegetation abundance in entire rings (using the section search method; Mazier et al., 2008). Vegetation data was then expressed in two different ways, as vegetation cover within the $10 \mathrm{~m}$ radius circle (the area-weighted mean of the rings or quadrats) and as distance-weighted plant abundance (using $z^{-1}$ as the weighting term since, as Fig. 3 shows, the weighting effects of

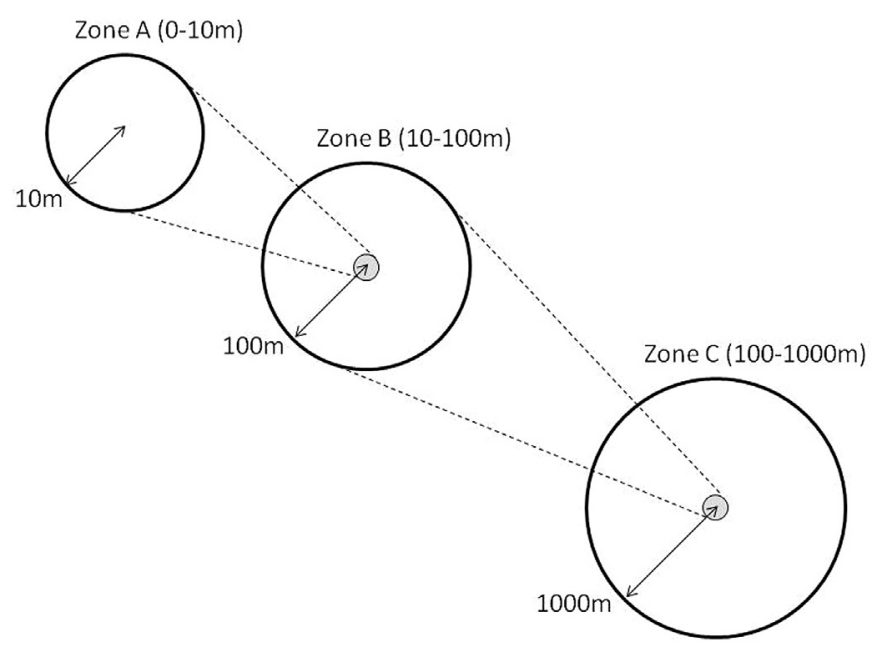

Fig. 4. Nesting of survey methods. this term are similar to those of the taxon-specific distance weighting function). This gave four measures of vegetation cover within the $10 \mathrm{~m}$ radius circle at each of the two habitats. Table 3 presents results of chi-squared tests of similarity for each pair of values. This shows that sampling, even with the sparse quadrat array shown in Fig. 6, and recording the whole area in rings produced statistically identical results $(p>0.05)$, supporting the argument that sampling is a sufficient strategy for ERV analysis data collection.

\section{Limitations in the vegetation survey methodology}

\subsection{Multiple recorders}

Fieldwork is time-consuming, and one way to collect data efficiently involves the use of multiple recorders. This in turn raises questions of inter-recorder error, especially when using a recording method such as visual estimates of cover which is only semiobjective (Vittoz and Guisan, 2007). Awareness of the possibility of recorder bias is a key tool in avoiding it. These problems can be minimised by initial training of all recorders and occasional 'calibration' throughout the field period, achieved by having all recorders record the same quadrat, compare results and modify their individual practice to conform to an agreed value. Where recorders are working in small teams, swapping members between teams also helps maintain reasonable standardisation of recording. Percentage cover estimates using a reduced, standardised scale ( + for single plants, $1-5 \%$, then $5 \%$ increments) also help avoid variation between recorders.

\subsection{Phenology and timing of recording}

Ideally, the pollen assemblage samples would be collected at the end of the flowering cycle (i.e. in late Autumn in the temperate zone), since if the current year's pollen is disproportionately represented in moss polster pollen assemblages (see Section 2.3 above) then ensuring that the full year's assemblage is represented will reduce the risk of biasing in favour of, for example, early-flowering species such as Corylus avellana which could occur in a sample collected in May, before later species such as Tilia cordata are releasing pollen. Vegetation composition also varies over the course of the year, especially for relatively short-lived and ephemeral herbaceous taxa; for example, spring ephemeral woodland species such as Hyacinthoides non-scripta can have abundances approaching $100 \%$ in April yet not be recorded as present in the same quadrat surveyed in August. The number of species that are recordable varies across the year (Losvik, 1991), suggesting that the best time for vegetation survey in a given habitat will often be much earlier in the field season than the preferred time for pollen sample collection. Many of the taxa of interest are relatively persistent in the vegetation (e.g. trees and Ericoids - their coverage remains fairly constant even though their identifiability may vary) but not all (e.g. grasses and forbs), suggesting that ideally vegetation surveys should be carried out at the same phenological point for each habitat. However, this is often not possible due to the costs or logistical challenges of revisiting locations. Empirical investigations of the extent to which this can alter the estimates of RPP are underway as part of the Crackles Bequest Project.

\subsection{Woodlands}

Sampling points within woodland present particular challenges, due to the multilayered nature of the vegetation (see Section 2.4.2 above). The sampling strategy adopted aims to balance effort with collecting data which might be needed at a future date (for 
Locate the sample site:

1) Use a hand-held GPS to get to the general location.

2) Identify a suitable pollen trap within the area; if at all possible, this needs to be a moss polster.

\section{Take the surface sample (or protect the future sampling location)}

1) Take a GPS reading of the actual location.

2) If not sampling the moss polster on this visit, cover the sampling point (e.g. with an inverted bucket) as soon as possible to prevent pollen disturbed by your movements landing on the sample point.

3) If sampling the polster on this visit:

- Label sample bag with site, sample code (if specified), collection team, date, coordinates.

- Collect a palm-sized sample of moss, cutting off plants growing through it and any soil.

- If the moss sample seems a bit small, or no moss is found, take a separate sample of soil by cutting a mini turf $0.5-1 \mathrm{~cm}$ thick and about $5 \mathrm{~cm} \times 5 \mathrm{~cm}$ in area.

- Seal sample into a second outer bag.

\section{Document the point}

1) Take a digital photo of the record sheet or the sample bag.

2) Leaving a marker in the sampled point, centre the $1 \mathrm{~m} \times 1 \mathrm{~m}$ quadrat with one edge facing north. Stand on the south side of the quadrat, facing north, and take a photograph of the quadrat looking down on the sampled point.

3) Take four photographs of the landscape, looking N, S, E and W from the sample point.

Record Zone A (0-10m):

1) Set out markers $10 \mathrm{~m}$ from the centre point at N, S, E, W.

2) Record the inner quadrat: Use visual estimates of cover, viewed from above, for ground vegetation (below c. $1.3 \mathrm{~m}$ ). List all the species present in the quadrat, then estimate cover for the minor species (using + for a single plant taking up less than 1\% (one quarter of a subdivision), 1-5\%, then multiples of $5 \%)$, then divide the remaining points between the major species. Also record cover of bare ground/rock/non-pollen-producing surfaces e.g. moss as needed. Each quadrat should total 100\%.

3) Lay a marked line from the centre marker to the north marker (line is marked at distances of 1.00, 2.25, 4.5 and $8 \mathrm{~m}$, the mid-points of each ring).

4) Record the four quadrats along the line - centre the quadrat over the mark on the line.

5) Search outwards from the outer quadrats (in the wedge NNW and NNE for the 6-10m ring and in the wedge NW to NE for the others), noting additional species not recorded in the quadrat. Record these species as present - ' $P$ '.

6) Move the line to midway between the $\mathrm{N}$ and $\mathrm{E}$ marker, on a bearing of approximately NE-SW. Record the 6-10 quadrat and search outwards for missed species (in the wedge NNE-ENE). New species in the wedge should be recorded as ' $P$ '.

7) Move the line to the E marker, record as above; continue until all quadrats are recorded for the full circle.

8) Use the record sheet to mark off each area as it is logged.

9) Record any canopy species (above c. $1.3 \mathrm{~m}$ ) which are present above the centre point of the quadrat (additional to the $100 \%$ cover of the lower vegetation).

10) If the polster was covered for later collection, uncover it once the risk of disturbance is past. 
Record Zone B (10-100m):

CREATE A MAP:

- Using aerial photograph or existing vegetation map, if available, create rough sketch.

- EITHER use a handheld GPS to map in the actual community boundaries OR walk 12 radial transects, marking the positions of community boundaries, and join points 'by eye'.

- Note position and species of single trees.

\section{CHARACTERISE EACH COMMUNITY}

In open communities:

- Randomly locate 4 quadrats $(1 \mathrm{~m} \times 1 \mathrm{~m})$ within blocks of relatively homogenous vegetation in each community and record each quadrat as described in Zone A point 2.

\section{In woodland communities:}

- Record up to 4 relevées in each community mapped, as follows:

- Mark the centre point of a $6 \mathrm{~m}$ radius relevée in a stand of relatively homogenous, representative vegetation (locate points randomly).

- Position a $6 \mathrm{~m}$ line marked at intervals representing equal area rings $(1.2 \mathrm{~m}, 2.9 \mathrm{~m}, 3.85 \mathrm{~m}, 4.6 \mathrm{~m}, 5.2 \mathrm{~m}$ and $5.75 \mathrm{~m}$ ) c. $1.3 \mathrm{~m}$ above the ground along the line running $\mathrm{N}$ from the centre point.

- At each point, record the species present below the line by using a plumb bob; record the first individual touched by the bob as it descends, or bare ground categories if no plant is present. Record canopy species above the point, using a mirror if necessary to avoid neck strain; if multiple canopy species overlap, record them all.

- Reposition the line and repeat until 8 radial lines have been recorded ( $N, N E, E$ etc.).

- If clearings or rides were mapped, record their composition as for open communities.

In mixed communities (e.g. Ulex heath or scrub areas):

- Set up $6 \mathrm{~m}$ relevée as described above. Record component present at each point (e.g. Ulex or open) to estimate the relative proportions of each patch in the mixed area.

- Then record the composition of each patch using the appropriate method (e.g. for a grassy area, use quadrats. For scrub areas use visual estimation (e.g. 100\% Ulex) or relevée).

Hedgerows and other linear communities (e.g. ditches):

- Lay out a $30 \mathrm{~m}$ tape along a representative section of the feature.

- Walk the length of the tape noting each species present.

- Estimate the abundance of each species along the $30 \mathrm{~m}$ section that you walked (note: in the case of hedgerows, percentages will typically add to over $100 \%$ as both woody and understorey species will be present - the vegetation is layered).

Fig. 5. (continued).

example, if a trunk-space transport component were added to the dispersal model for samples collected from small gaps or under closed canopy). If the current model assumptions were strictly adhered to, there would be no need to record the ground flora in any part of the surveying method.

\subsection{Community composition in the wider landscape}

In the outer zone of the survey system (zone C in Fig. 4), vegetation data is collected from a variety of sources in different studies.
A particular challenge here is translating data on vegetation collected for different purposes to be compatible with the vegetation survey methods used in the inner layers. Poska et al. (2011) discussed use of CORINE data as a basis for vegetation maps, and found that it produced similar pollen productivity estimates as using a more detailed vegetation dataset based on state forest data. There are differences in CORINE data classification across national boundaries, but there are also differences in data recorded for other purposes, such as forestry records. Twiddle et al. (2012) used forestry data for a study in Scotland, since spatially explicit records 


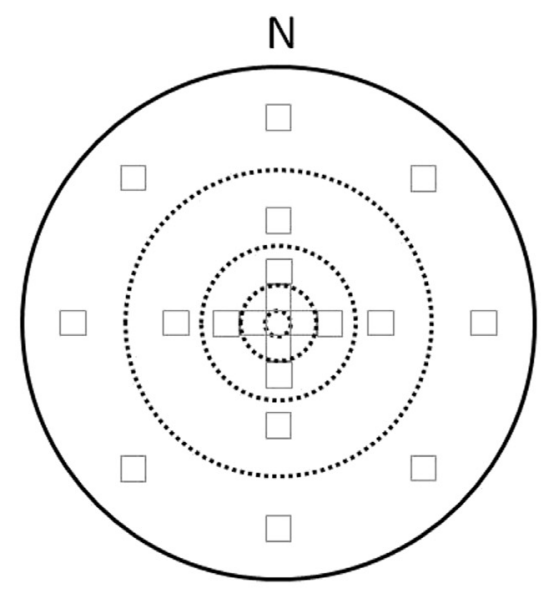

This strategy samples: $100 \%$ of $0.5 \mathrm{~m}$ ring $64 \%$ of $1.5 \mathrm{~m}$ ring $19 \%$ of $3 \mathrm{~m}$ ring $5 \%$ of $6 \mathrm{~m}$ ring $4 \%$ of $10 \mathrm{~m}$ ring

The dashed circles are $0.5 \mathrm{~m}, 1.5 \mathrm{~m}, 3 \mathrm{~m}$ and $6 \mathrm{~m}$ in radius

They divide zone $\mathrm{A}$ into bands, each sampled by the quadrats shown

The outer circle is $10 \mathrm{~m}$ in radius

Each square (=quadrat) is $1 \mathrm{~m} \times 1 \mathrm{~m}$

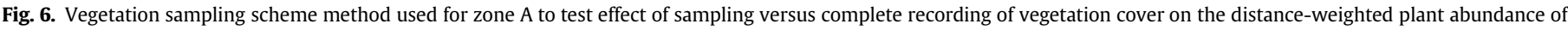
the main taxa.

of species structure, demographics, planted density and thinning events were all available, in some cases covering more than 100 years. The appropriate combination of data sources, balancing data processing time with collection of sufficient information, cannot be prescribed for all locations easily. For the Crackles Bequest Project, we will combine national mapping with aerial images from free online sources to define the main community boundaries in zone $C$, matching the communities to those recorded in zone $\mathrm{B}$, and assuming constant vegetation composition.

\subsection{Boundaries between vegetation units}

The model of pollen dispersal and deposition ignores any 'edge effects' linked to patches of vegetation, whether these are abrupt changes in vegetation height or enhanced flowering (and hence pollen production) at margins, such as can occur in field margins or at woodland edges. Abrupt height changes in the physical landscape usually reflect human activity. The existence of edge effects is illustrated in Fig. 7, which shows simulated tree pollen percentages at sample points around a woodland fragment in a moorland landscape compared with empirical data collected from moorland habitats close to woodland fragments in Assynt, north-western Scotland (see Bunting, 2002 for more details). In simulation, tree pollen proportions drop to around $20 \%$ of the total as soon as the sample is located in heath vegetation, but in the empirical data a range of values are seen, with values as low as $20 \%$ tree pollen only

Table 3

Results of statistical comparison of vegetation sampling and recording in zone A.

\begin{tabular}{|c|c|c|c|c|}
\hline $\begin{array}{l}\text { Vegetation } \\
\text { community }\end{array}$ & $\begin{array}{l}\text { Vegetation data } \\
\text { processing } \\
\text { strategy }\end{array}$ & $\chi^{2}$ & $\begin{array}{l}\text { Degrees of } \\
\text { freedom }\end{array}$ & $\begin{array}{l}p \text { (probability of } \\
\text { obtaining the stated } \\
\text { value of the } \chi^{2} \\
\text { statistic given the } \\
\text { degrees of freedom } \\
\text { if the two } \\
\text { distributions are } \\
\text { actually identical) }\end{array}$ \\
\hline Maritime heath & Area weighted & 25.763 & 16 & 0.057 \\
\hline Maritime heath & Distance-weighted & 20.163 & 16 & 0.213 \\
\hline Grazed grassland & Area weighted & 4.813 & 12 & 0.964 \\
\hline Grazed grassland & Distance-weighted & 6.379 & 12 & 0.900 \\
\hline
\end{tabular}

recorded consistently in samples more than $50 \mathrm{~m}$ from the edge of the woodland. This enhanced representation of taller vegetation beyond the patch edge is not incorporated in the model. It is likely that there is also a less significant 'inwards' effect of pollen being carried into the trunk space rather than up and over the canopy,

a

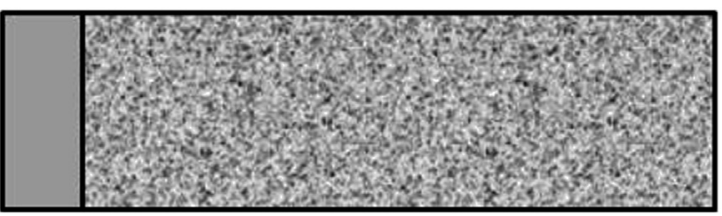

Woodland Patchy moorland

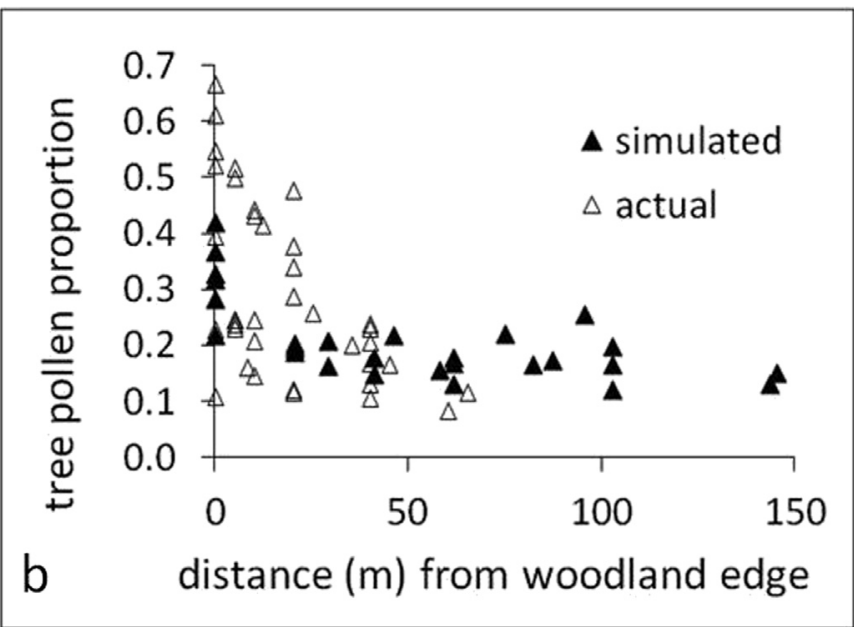

Fig. 7. Example of mismatch between empirical and simulated pollen signal at boundary between vegetation units. a) shows a schematic of the modelled situation, where birch woodland with a well defined edge abuts a patchy moorland community. b) compares the proportion of tree pollen recorded at different points within the moorland simulated using the Sutton-Prentice model of pollen dispersal and deposition (solid symbols) with empirical data from a study of pollen deposition around birch woodland fragments in north-west Scotland (Bunting, 2002) (open symbols). The dashed line outlines empirical data points in the 'edge zone' which are not replicated by the model. 
since Raynor et al. (1974) traced grains from the woodland edge up to $100 \mathrm{~m}$ into the woodland. Based on the empirical data from north-west Scotland (Bunting, 2002) and elsewhere, a $50 \mathrm{~m}$ exclusion zone around the edges of woodlands has been applied in some surface sample projects (Bunting et al., 2005; Waller et al., 2012).

Individual trees and hedgerows in predominantly open landscapes present similar challenges. Pollen is produced by woody and climbing hedgerow plants a substantial distance above the general vegetation canopy, and some pollen being transported just above that canopy is probably removed from the air stream by impact on hedge structural elements. On this basis, a buffer zone around the edge of the chosen landscape fragments is used to prevent sample points being located in these marginal areas, although some samples may still be within $50 \mathrm{~m}$ of a woodland edge, hedge, single tree or a clearing within a woodland. Further investigation of the effects of height variations is probably warranted.

\section{Conclusion}

The review of factors affecting the way in which the pollen signal at a single point represents the surrounding vegetation shows many gaps in our current understanding. However, there is enough empirical evidence supporting the main features of the pollen dispersal and deposition models described to encourage their use in quantitative reconstruction of past vegetation cover. Such use requires calibration of the model, and this paper presents a methodology for vegetation survey and pollen sample collection for this purpose. The proposed methodology is pragmatic, designed to be replicable by different research groups, usable in a wide range of habitats, and uses minimum effort to collect adequate data for model calibration rather than representing some ideal or required approach. Although the focus of current work and the papers cited here is in the temperate deciduous forest biome region of the northern hemisphere, the principles discussed are sufficiently general that the method should be appropriate for all terrestrial habitats.

\section{Acknowledgements}

The authors thank PolLandCal network members, particularly Shinya Sugita and Marie-José Gaillard, for many fruitful discussions of the research topic, and all attendees at the May 2010 workshop in Hull who contributed to the discussions summarised in this paper. L. Tunnicliff helped MJB and MF with vegetation survey for the maritime heath case study. This is paper number 1 from the Crackles Bequest Project, funded by the University of Hull via a bequest from the will of Dr F. Eva Crackles.

\section{Appendix A. Supplementary data}

Supplementary data related to this article can be found at http:// dx.doi.org/10.1016/j.quascirev.2013.10.006.

\section{References}

Abraham, V., Kozáková, R., 2012. Relative pollen productivity estimates in the modern agricultural landscape of Central Bohemia (Czech Republic). Rev. Palaeobot. Palynol. 179, 1-12.

Andersen, S.T., 1970. The Relative Pollen Productivity and Pollen Representation of North European Trees, and Correction Factors for Tree Pollen Spectra. In: Dan. Geol. Unders, vol. 96, pp. 1-99.

Andersen, S.T., 1973. The differential pollen productivity of trees and its significance for the interpretation of pollen diagrams from a forested region. In: Birks, H.J.B., West, R.G. (Eds.), Quaternary Plant Ecology. John Wiley and Sons, New York, pp. 109-115.
Behre, K.E., 1981. The interpretation of anthropogenic indicators in pollen diagrams Pollen Spores 23, 225-245.

Boyd, W.E., 1986. The role of mosses in modern pollen analysis: the influence of moss morphology on pollen entrapment. Pollen Spores 28, 243-256.

Bradshaw, R.H.W., 1981. Modern pollen representation factors for woods in southwest England. J. Ecol. 69, 45-70.

Broström, A., Sugita, S., Gaillard, M.J., Pilesjö, P., 2005. Estimating the spatial scale of pollen dispersal in the cultural landscape of southern Sweden. Holocene 15 $252-262$.

Broström, A., Nielsen, A.B., Gaillard, M.J., Hjelle, K., Mazier, F., Binney, H., Bunting, J., Fyfe, R., Meltsov, V., Poska, A., Räsänen, S., Soepboer, W., Stedingk, H.v., Suutari, H., Sugita, S., 2008. Pollen productivity estimates of key European plant taxa for quantitative reconstruction of past vegetation: a review. Veg. Hist. Archaeobotany 17, 461-468.

Broström, A., Sugita, S., Gaillard, M.J., 2004. Pollen productivity estimates for the reconstruction of past vegetation cover in the cultural landscape of southern Sweden. Holocene 14, 368-381.

Bunting, M.J., 2002. Detecting woodland remnants in cultural landscapes: modern pollen deposition around small woodlands in north-west Scotland. Holocene 12, 291-301.

Bunting, M.J., 2003. Pollen-based reconstruction of cultural landscapes: an investigation of pollen source area for non-arboreal taxa. Rev. Palaeobot. Palynol. 125 285-298.

Bunting, M.J., 2008. Pollen in wetlands: using simulations of pollen dispersal and deposition to better interpret the pollen signal. Biodivers. Conserv. 19, 2079 2096.

Bunting, M.J., Armitage, R., Binney, H.A., Waller, M., 2005. Estimates of relative pollen productivity and relevant source area of pollen for major tree taxa in two Norfolk (UK) woodlands. Holocene 15, 459-465.

Bunting, M.J., Hjelle, K.L., 2010. Effect of vegetation data collection strategies on estimates of relevant source area of pollen (RSAP) and relative pollen productivity (RPP) for non-arboreal taxa. Veg. Hist. Archaeobotany 19, 365-374.

Bunting, M.J., Middleton, R., 2005. Modelling pollen dispersal and deposition using HUMPOL software: simulating wind roses and irregular lakes. Rev. Palaeobot. Palynol. 134, 185-196.

Bunting, M.J., Middleton, R., 2009. The Multiple Scenario Approach - a pragmatic method for past vegetation mosaic reconstruction. Holocene 19, 799-803.

Bunting, M.J., Schofield, J.E., Edwards, K.J., 2013. Estimates of relative pollen productivity (RPP) for selected taxa from southern Greenland: a pragmatic solution. Rev. Palaeobot. Palynol. 190, 66-74.

Calcote, R., 1995. Pollen source area and pollen productivity: evidence from forest hollows. J. Ecol. 83, 591-602.

Caseldine, C., Fyfe, R., Langdon, C., Thompson, G., 2007. Simulating the nature of vegetation communities at the opening of the Neolithic on Achill Island, County Mayo, Ireland - the potential role of models of pollen dispersal and deposition. Rev. Palaeobot. Palynol. 144, 135-144.

Caseldine, C.J., 1981. Surface pollen studies across Bankhead Moss, Fife, Scotland J. Biogeogr. 8, 7-25.

Davis, M., 1963. On the theory of pollen analysis. Am. J. Sci. 261, 897-912.

Davis, M., 2000. Palynology after Y2K - understanding the source area of pollen in sediments. Ann. Rev, Earth Planet. Sci. 28, 1-18.

Fisher, R.A., 1912. On an absolute criterion for fitting frequency curves. Messenger Math. 41, 155-160.

Gaillard, M.J., Birks, H.J.B., Emmanuelson, U., Karlson, S., Lagerås, P., Olausson, D. 1994. Application of modern pollen/land-use relationships to the interpretation of pollen diagrams reconstruction of land-use history in south Sweden. Rev. Palaeobot. Palynol. 82, 47-73.

Gaillard, M.J., Sugita, S., Mazier, F., Trondman, A.L., Broström, A., Hickler, T. Kaplan, J.O., Kjellstrom, E., Kokfelt, U., Kunes, P., Lemmen, C., Miller, P., Olofsson, J. Poska, A., Rundgren, M., Smith, B., Strandberg, G., Fyfe, R., Nielsen, A.B., Alenius, T., Balakauskas, L., Barnekow, L., Birks, H.J.B., Bjune, A., Bjorkman, L., Giesecke, T., Hjelle, K., Kalnina, L., Kangur, M., van der Knaap, W.O., Koff, T., Lageras, P. Latalowa, M., Leydet, M., Lechterbeck, J., Lindbladh, M., Odgaard, B., Peglar, S., Segerstrom, U., von Stedingk, H., Seppa, H., 2010. Holocene land-cover reconstructions for studies on land cover-climate feedbacks. Clim. Past 6, 483-499.

Gillson, L., Duffin, K.I., 2007. Thresholds of potential concern as benchmarks in the management of African savannahs. Phil. Trans. R. Soc. B 362, 309-319.

Hellman, S., Gaillard, M.J., Broström, A., Sugita, S., 2008. The REVEALS model, a new tool to estimate past regional plant abundance from pollen data in large lakes validation in southern Sweden. J. Quat. Sci. 23, 21-42.

Hicks, S., 2001. The use of annual arboreal pollen deposition values for delimiting tree-lines in the landscape and exploring models of pollen dispersal. Rev. Palaeobot. Palynol. 117, 1-29.

Hjelle, K.L., 1998. Herb pollen representation in surface moss samples from mown meadows and pastures in western Norway. Veg. Hist. Archaeobotany 7, 79-96.

Hjelle, K.L., 1999a. Modern pollen assemblages from mown and grazed vegetation types in western Norway. Rev. Palaeobot. Palynol. 107, 55-81.

Hjelle, K.L., 1999b. Use of modern pollen samples and estimated pollen representation factors as aids in the interpretation of cultural activity in local pollen diagrams. Nor. Archaeol. Rev. 32, 19-39.

Hjelle, K.L., Sugita, S., 2012. Estimating pollen productivity and relevant source area of pollen using lake sediments in Norway: how does lake size variation affect the estimates? Holocene 22, 313-324.

Jackson, S.T., 1994. Pollen and spores in Quaternary lake sediments as sensors of vegetation composition: theoretical models and empirical evidence. In 
Traverse, A. (Ed.), Sedimentation of Organic Particles. Cambridge University Press, Cambridge, pp. 253-286.

Jackson, S.T., Kearsley, J.B., 1998. Quantitative representation of local forest composition in forest-floor pollen assemblages. J. Ecol. 86, 474-490.

Jackson, S.T., Lyford, M.E., 1999. Pollen dispersal models in Quaternary plant ecology: assumptions, parameters, and prescriptions. Bot. Rev. 65, 39-75.

Kuneš, P., Pelánková, B., Chytrý, M., Jankovská, V., Pokorný, P., Libor, P., 2008. Interpretation of the last-glacial vegetation of eastern-central Europe using modern analogues from southern Siberia. J. Biogeogr. 35, 2223-2236.

Lisitsyna, O., Hicks, S., Huusko, A., 2012. Do moss samples, pollen traps and modern lake sediments all collect pollen in the same way? A comparison from the forest limit area of northernmost Europe. Veg. Hist. Archaeobotany 21, 187-199.

Losvik, M.H., 1991. A hay meadow in western Norway - changes in the course of a growing season. Nord. J. Bot. 11, 577-586.

Maher Jr., L., 1972. Nomograms for computing 0.95 confidence limits of pollen data. Rev. Palaeobot. Palynol. 13, 85-93.

Matthias, I., Nielsen, A.B., Giesecke, T., 2012. Evaluating the effect of flowering age and forest structure on pollen productivity estimates. Veg. Hist. Archaeobotany 21, 471-484.

Mazier, F., Galop, D., Brun, C., Buttler, A., 2006. Modern pollen assemblages from grazed vegetation in the Western Pyrenees Mountains (France): a numerical tool for more precise reconstruction of past cultural landscapes. Holocene 16, 91-103.

Mazier, F., Broström, A., Gaillard, M.J., Sugita, S., Vittoz, P., Buttler, A., 2008. Pollen productivity estimates and relevant source area for major taxa in a pasture woodland (Jura Mountains, Switzerland). Veg. Hist. Archaeobotany 17, 479496.

Mazier, F., Galop, D., Gaillard, M.-J., Rendu, C., Cugny, C., Amaïa, L., Peyron, O. Buttler, A., 2009. Multidisciplinary approach to reconstructing pastoral activ ities: an example from the Pyrenean Mountains (Pays Basque). Holocene 19 $171-188$.

Mazier, F., Gaillard, M.J., Kuneš, P., Sugita, S., Trondman, A.K., Broström, A., 2012a. Testing the effect of site selection and parameter setting on REVEALS-mode estimates of plant abundance using the Czech Quaternary Palynological Database. Rev. Palaeobot. Palynol. 187, 38-49.

Mazier, F., Nielsen, A.B., Broström, A., Sugita, S., Hicks, S., 2012b. Signals of tree volume and temperature in a high-resolution record of pollen accumulation rates in northern Finland. J. Quat. Sci. 27 (6), 564-574.

Mulder, C., Janssen, C.R., 1998. Application of Chernobyl Caesium-137 fallout and naturally occurring lead-210 for standardization of time in moss samples: recent pollen-flora relationships in the Allgäuer Alpen, Germany. Rev. Palaeobot. Palynol. 103, 23-40.

Mulder, C., Janssen, C.R., 1999. Occurence of pollen and spores in relation to presentday vegetation in a Dutch heathland area. J. Veg. Sci. 10, 87-100.

Ni, J., Yu, G., Harrison, S.P., Prentice, I.C., 2010. Palaeovegetation in China during the late Quaternary: biome reconstructions based on a global scheme of plant functional types. Palaeogeog. Palaeoclim. Palaeoecol. 289, 44-61.

Nielsen, A.B. Møller, P.F., Giesecke, T. Stavngaard, B., Fontana, S.L. Bradshaw, R.H.W., 2010. The effect of climate conditions on inter-annual flowering variability monitored by pollen traps below the canopy in Draved Forest, Denmark. Veg. Hist. Archaeobotany 19, 309-323.

Nielsen, A.B., Odgaard, B.V., 2004. The use of historical analogues for interpreting fossil pollen records. Veg. Hist. Archaeobotany 13, 33-43.

Overpeck, J.T., Webb, T., Prentice, I.C., 1985. Quantitative interpretation of fossi pollen spectra - dissimilarity coefficients and the method of modern analogs. Quat. Res. 23, 87-108.

Parsons, R.W., Prentice, I.C., 1981. Statistical approaches to R-values and the pollenvegetation relationship. Rev. Palaeobot. Palynol. 32, 127-152.

Poska, A., Meltsov, V., Sugita, S., Vassiljev, J., 2011. Relative pollen productivity estimates of major anemophilous taxa and relevant source area of pollen in a cultural landscape of the hemi-boreal forest zone (Estonia). Rev. Palaeobot. Palynol. 167, 30-39.

Prentice, C.I., Parsons, R.W., 1983. Maximum likelihood linear calibration of pollen spectra in terms of forest composition. Biometrics 39, 1051-1057.

Prentice, I.C., 1985. Pollen representation, source area, and basin size: toward a unified theory of pollen analysis. Quat. Res. 23, 76-86.

Prentice, I.C., 1988. Records of vegetation in time and space: the principles of pollen analysis. In: Huntley, B., Webb III, T. (Eds.), Vegetation History. Kluwer Academic Publishers, Dordrecht, pp. 17-42.

Prentice, I.C., Guiot, J., Huntley, B., Jolly, D., Cheddadi, R., 1996. Reconstructing biomes from palaeoecological data: a general method and its application to European pollen data at 0 and 6 ka. Clim. Dyn. 12, 185-194.

Prentice, I.C., Jolly, D., BIOME 6000 participants, 2000. Mid-Holocene and glacialmaximum vegetation geography of the northern continents and Africa. J. Biogeogr. 27, 507-519.

Räsänen, S., Hicks, S., Odgaard, B.V., 2004. Pollen deposition in mosses and in a modified 'Tauber trap' from Hailuoto, Finland: what exactly do the mosses record? Rev. Palaeobot. Palynol. 129, 103-116.

Räsänen, S., Suutari, H., Nielsen, A.B., 2007. A step further towards quantitative reconstruction of past vegetation in Fennoscandian boreal forests: pollen productivity estimates for six dominant taxa. Rev. Palaeobot. Palynol. 146, 208-220.

Raynor, G.S., Hayes, J.V., Ogden, E.C., 1974. Particulate dispersion into and within a forest. Bound. Layer Meteorol. 7, 429-456.

Soepboer, W., Sugita, S., Lotter, A.F., van Leuwen, J.F.N., van der Knaap, W.O., 2007. Pollen productivity estimates for quantitative reconstruction of vegetation cover on the Swiss Plateau. Holocene 17, 65-77.

Sugita, S., 1993. A model of pollen source area for an entire lake surface. Quat. Res. 39, 239-244.

Sugita, S., 1994. Pollen representation of vegetation in Quaternary sediments: theory and method in patchy vegetation. J. Ecol. 82, 881-897.

Sugita, S., 2007a. Theory of quantitative reconstruction of vegetation. I. Pollen from large sites REVEALS regional vegetation composition. Holocene 17, 229-241.

Sugita, S., 2007b. Theory of quantitative reconstruction of vegetation. II. All you need is LOVE. Holocene 17, 243-257.

Sugita, S., Gaillard, M.-J., Broström, A., 1999. Landscape openness and pollen records: a simulation approach. Holocene 9, 409-421.

Sugita, S., Hicks, S., Sormunen, H., 2010a. Absolute pollen productivity and pollenvegetation relationships in northern Finland. J. Quat. Sci. 25, 724-736.

Sugita, S., Parshall, T., Calcote, R., Walker, K., 2010b. Testing the Landscape Reconstruction Algorithm for spatially explicit reconstruction of vegetation in northern Michigan and Wisconsin. Quat. Res. 74, 289-300.

Sutton, O.G., 1953. Micrometeorology. McGraw-Hill, New York.

Tauber, H., 1965. Differential Pollen Dispersion and the Interpretation of Pollen Diagrams. In: Dan. Geol. Unders, vol. 89, pp. 1-69.

Tauber, H., 1967. Investigations of the mode of pollen transfer in forested areas. Rev. Palaeobot. Palynol. 3, 277-286.

Tipping, R., Bunting, M.J., Davies, A.L., Murray, H., Fraser, S., McCulloch, R., 2009. Modelling land use around an early Neolithic timber 'hall' in north east Scotland from high spatial resolution pollen analyses. J. Arch. Sci. 36, 140-149.

Twiddle, C.L., Jones, R.T., Caseldine, C.J., Sugita, S., 2012. Pollen productivity estimates for a pine woodland in eastern Scotland: the influence of sampling design and vegetation patterning. Rev. Palaeobot. Palynol. 174, 67-78.

Vittoz, P., Guisan, A., 2007. How reliable is the monitoring of permanent vegetation plots? A test with multiple observers. J. Veg. Sci. 18, 413-422.

von Stedingk, H., Fyfe, R., Allard, A., 2008. Pollen productivity estimates for the reconstruction of past vegetation at the forest tundra ecotone. Holocene 18, $323-332$.

Waller, M., Grant, M.J., Bunting, M.J., 2012. Modern pollen studies from coppiced woodlands and their implications for the detection of woodland management in Holocene pollen records. Rev. Palaeobot. Palynol. 187, 11-28. 